University at Albany, State University of New York

Scholars Archive

\title{
Generating Dynamic Democratic Discussions: An Analysis of Teaching with US Presidential Debates
}

\author{
Brett L.M. Levy \\ University at Albany, State University of New York, bllevy@albany.edu \\ Lauren Collet \\ University at Albany, State University of New York, Icollet@albany.edu \\ Thomas C. Owenby \\ University of Wisconsin-Madison
}

Follow this and additional works at: https://scholarsarchive.library.albany.edu/etap_fac_scholar

Part of the Curriculum and Instruction Commons

\section{Recommended Citation}

Levy, Brett L.M.; Collet, Lauren; and Owenby, Thomas C., "Generating Dynamic Democratic Discussions: An Analysis of Teaching with US Presidential Debates" (2017). Educational Theory and Practice Faculty Scholarship. 26.

https://scholarsarchive.library.albany.edu/etap_fac_scholar/26

This Article is brought to you for free and open access by the Educational Theory and Practice at Scholars Archive. It has been accepted for inclusion in Educational Theory and Practice Faculty Scholarship by an authorized administrator of Scholars Archive. For more information, please contact scholarsarchive@albany.edu. 


\title{
Generating Dynamic Democratic Discussions:
}

\section{An Analysis of Teaching with US Presidential Debates}

\author{
Brett L. M. Levy \\ University at Albany, State University of New York \\ Lauren Collet \\ University at Albany, State University of New York \\ Thomas C. Owenby \\ University of Wisconsin-Madison
}

Citation Information of Original Publication:

Levy, B. L. M., Collet, L., \& Owenby, T. C. (2017). Generating dynamic democratic discussions: An analysis of teaching with US presidential debates. The Social Studies, 108(2), 39-54. DOI: 10.1080/00377996.2016.1266594

\section{Acknowledgements:}

The study presented in this paper was funded by the Spencer Foundation's New Civics Initiative (Grant \#201300013), and we are very grateful for their support. We would also like to thank Brian Towns and Ryan May for their assistance with data collection, and Constance Flanagan and Diana Hess for their guidance in study design. In addition, we extend our deepest appreciation to the teachers and students who participated in this study and openly shared their experiences and perspectives with us. 
Generating Dynamic Democratic Discussions:

An Analysis of Teaching with US Presidential Debates

\begin{abstract}
Researchers have found that when young people participate in discussions of controversial political issues, they often become more politically engaged and informed (Hess 2009). Nonetheless, some educators avoid fostering such discussions because they can become heated and thus distract from academic learning (Hess 2002). Presidential elections, including the highly publicized debates, provide substantial material for discussions of major national and international issues, but no published research has examined how educators can leverage these events to generate productive civic learning experiences. In this paper, we analyze data collected in seven high school classrooms during the 2012 presidential election to examine the challenges and opportunities associated with generating substantive, dynamic discussions of presidential debates. Our findings indicate that students enjoyed learning about candidates' different perspectives and that certain strategies were especially helpful for fostering substantive discussions: (a) scaffolding students' preparation for discussion, (b) providing opportunities for students to address open-ended questions, (c) redirecting students' engagement in competitive, interpersonal dynamics to learning about the issues, and (d) countering students' partisan tendencies. We discuss implications for practice and research and present a conceptual framework for generating dynamic, substantive democratic discussions.
\end{abstract}


"The election is really a lever to drive other types of learning more deeply." - Ms. Galliano, Government Teacher \& Study Participant

In democratic societies, discussing public issues is essential for navigating disagreements, negotiating compromises, and developing common understandings (Gutmann \& Thompson 1996). For decades, scholars in social studies education have encouraged educators to foster discussions of controversial issues, such as gun control, abortion, and energy policy (e.g., Passe \& Evans 1996; Parker 2001). Indeed, researchers have found that discussing such topics can support young people's civic engagement and critical thinking skills (Hess 2009; Hess \& McAvoy 2015). Based on this research, standards at the state and national levels emphasize deliberation as a central civic skill. For example, the College, Career, and Civic Life (C3) standards suggest that by the end of grade 8, students should "compare deliberative processes used by a wide variety of groups in various settings," and by the end of grade 12, they should "use appropriate deliberative processes in multiple settings" (NCSS, 2013, p.33).

High-profile political events, such as presidential debates, can surface different perspectives on a variety of serious issues (e.g., trade, abortion, tax rates, health care policies) and animate strong emotions (Costello, 2016), so discussing their content can enable students to consider vital national issues, practice central civic skills, and reflect on their own political identities. However, little prior research has examined how teachers leverage these national media events to generate classroom discussions. In this article we draw on data collected in seven classrooms during the 2012 presidential election to 
explore opportunities and challenges associated with fostering content-rich, interactive discussions of presidential debates. Then, building on these findings and prior research, we present a conceptual framework for generating dynamic, substantive democratic discussions.

\section{Background}

To frame this study, we consider earlier research related to teaching about current controversial public issues, including the rationales for engaging in such work and the challenges involved. First and foremost, numerous studies suggest that young people experience substantial civic learning from participating in discussions of controversial issues, including the development of political tolerance (Avery, Bird, Johnstone, Sullivan, \& Thalhammer 1992), analytical thinking skills (Johnston, Anderman, Milne, Klenck, \& Harris 1994), and civic participation capacities (Condon 2015; McDevitt \& Kiousis 2006). These findings align with the arguments of political and educational theorists who contend that exchanging ideas about public controversies enable us to surface our value differences (Gutmann \& Thompson 1996) and to reach carefully reasoned, evidence-based decisions (Parker 2006). Furthermore, researchers have found that participating in discussions of authentic problems is associated with deeper learning in a variety of subject areas, including science (Smith, Wood, Adams, Wieman, Knight, Guild, \& Su 2009), English language arts (Applebee, Langer, Nystrand, \& Gamoran 2003), and social studies (Newman, King, \& Carmichael 2007).

Despite these potential benefits, guiding discussions can be quite challenging for educators. Teachers may have difficulty stimulating substantive, content-rich exchanges for a variety of reasons, such as students' lack of relevant background knowledge (Kus 2015) 
and students' concerns about what their peers will think of their comments (Hess \& Posselt 2002; Rossi 1995). Perhaps as a result of these challenges, educators tend to dedicate relatively little classroom time to discussion, and these brief experiences are often unsupportive of students' conceptual exploration (Nystrand, 1997). Some hopeful research, however, indicates that discussions can be more sustained and dynamic when educators foster an open environment where new ideas can freely be shared (Brice, 2002; Godfrey \& Grayman 2014), when students are regularly invited to respond to one another's comments and ask authentic questions (Nystrand, Wu, Gamoran, Zeiser, \& Long 2003), and during instruction with purposeful goals and exchanges of ideas (Parker 2001). Indeed, there is evidence that even teachers accustomed to more traditional recitation pedagogies can learn to develop such a "dialogic stance" (Wells \& Arauz 2006) - and that with appropriate scaffolding, students can adopt more democratic discourse (Flynn, 2009). The present study builds on this prior research by examining how educators can and do foster dynamic, substantive discussions about specific high-visibility current events - political debates. Integrating current events into classroom instruction may offer major affordances for students, such as boosting their political engagement (Levy, 2011, 2013) and strengthening their interest in related content (Deveci 2007). Indeed, for decades, researchers of "issues-centered" education have argued that guiding students to explore sociopolitical topics and controversies, rather than to recall discrete facts, should be an organizing principle of social studies education (Hahn 1996; Ochoa-Becker 1996, 2007; Shaver 1992). Drawing on Dewey $(1915,1933)$ and Bruner $(1960)$, these scholars contend that preparing to participate in democratic society requires practicing authentic problem 
solving and decision making related to public issues (Engle \& Ochoa 1988) and that current events can provide useful, engaging content for such explorations (Hess 2008).

Many teachers agree. In a study that included 223 high school social studies teachers, Haas and Laughlin (2000) found that most of these educators introduced current events into their classrooms several times per week and found them to be useful for fostering various student skills, such as defining problems and identifying biases. However, raising awareness of current issues and public debates may be insufficient. In her close qualitative research of social studies teachers, Bickmore (1993) concluded that exposure to current controversial issues ("conflictual content") was vital but that actually confronting and grappling with such content ("conflictual pedagogy") was essential for the development of democratic citizenship. Several scholars have analyzed how educators can skillfully guide students to examine multiple sides of controversial issues (e.g., Hess \& McAvoy 2015), but there has been limited research on how educators teach about presidential elections.

Some valuable studies have explored pedagogies for exploring candidates' backgrounds (Journell 2011a) and positions (Journell 2011b), and others have documented students' civic development through election simulations (Coffey, Miller \& Feuerstein 2011; Day, Boeckelman, LaFrance, Hardy \& Rohall 2012) and disciplinary literacy strategies (Journell, Beeson, \& Ayers 2015). And our own recent study found that watching and then discussing presidential debates can strengthen students' political interest (Levy, Solomon, \& Collet-Gildard, 2016). Given the widespread public attention to presidential debates, it is important to examine how educators guide students to discuss and analyze these events, and the research below begins to fill in this research gap. In this article, we 
draw on the aforementioned research and an academic discussion framework (Elizabeth, Anderson, Snow, \& Selman 2012) to analyze how teachers can foster discussions that generate not only students' participation but also their conceptual exploration of political issues.

\section{Methods}

\section{Research Questions}

The overarching research question guiding this study was: How can educators guide students to engage in dynamic and substantive discussions of presidential debates? As we explored this question, we also examined students' engagement in postdebate discussions, challenges teachers encountered when guiding these discussions, and pedagogies that appeared to lead students towards exchanges involving diverse perspectives.

\section{Study Contexts}

To address these research questions, we examined data from a larger study of teaching and learning related to the 2012 presidential election. These data were collected in four high schools in the same Midwestern "swing state" during the fall semester of the 2012-13 academic year. The schools were located in three districts with different dominant political orientations, according to prior voting records. Whereas Red Rock High School (all names of schools and individuals are pseudonyms) was located in a predominantly Republican area, Blue Lake North High School and Blue Lake South High School were in a strongly Democratic community. Meanwhile, Centerville High School was in a more ideologically mixed area. Students at these schools were predominantly middle class, but Blue Lake South had a larger proportion of socioeconomically disadvantaged students than the other schools (see Table 1). 
Table 1

Characteristics of study sites' student populations

\begin{tabular}{lcccc}
\hline Characteristic/School & Red Rock & Centerville & Blue Lake North & $\begin{array}{c}\text { Blue Lake } \\
\text { South }\end{array}$ \\
\hline Approx. Number of Students & 1,200 & 450 & 2,100 & 1,500 \\
White & $85 \%$ & $79 \%$ & $53 \%$ & $39 \%$ \\
Economically Disadvantaged & $17 \%$ & $37 \%$ & $34 \%$ & $57 \%$ \\
Limited English & $1 \%$ & $3 \%$ & $11 \%$ & $15 \%$ \\
\hline
\end{tabular}

The research team, which included the first and third authors and two additional researchers, focused on exploring interactions and learning in seven social studies courses studying the election (CSEs), all of which included some explorations of the presidential debates. At Red Rock and Centerville, CSEs were each school's required U.S. Government courses (see Table 2). The Blue Lake district did not have this requirement, so we examined elective classes in contemporary issues (BL North only) and government (both schools).

Table 2

Teacher participants and schools

\begin{tabular}{lll}
\hline Teacher & Course & School \\
\hline Ms. Allen & AP Government & Red Rock High School \\
Mr. Robinson & Government & Red Rock High School \\
Mr. Kent & Government & Red Rock High School \\
Mr. Bristol & Political Science & Centerville High School \\
Mr. Kushner & Contemporary Issues & Blue Lake North High School \\
Ms. Galliano & AP Government & Blue Lake North High School \\
Mr. Atherton & Government & Blue Lake South High School \\
\hline
\end{tabular}

\section{Data Collection}

In all four schools, we collected data through observing class meetings and conducting semistructured interviews with students. (The larger study also involved surveys at three time points during the semester.) During our observations in all seven 
classrooms we recorded field notes on student-teacher interactions related to the presidential debates - keeping records of activity structures, curricular materials used, time spent on different activities, and the content and tone of individuals' comments. The relevant observations included 26 class periods. In addition, we interviewed teachers $(\mathrm{N}=7)$ about their experiences teaching about the election, including the debates, and we conducted student interviews that explored which class activities most supported their political engagement. Interviewees were purposefully selected (Patton, 1990) to maximize variation of political perspectives, demographics, and initial political engagement.

\section{Data Analysis}

To analyze observation field notes and interview transcripts, we conducted constant comparative analysis (Glaser \& Strauss, 1967; Strauss \& Corbin, 1999), which involved several rounds of coding. Using the larger data set, we identified experiences that appeared to support youth political engagement (coded as "opportunities") and various difficulties associated with these activities (labeled "challenges"). After discussing debates emerged as a major pedagogical opportunity, we examined related data more closely, aiming to identify how teachers generated substantive (content-rich), dynamic exchanges among students and teachers about presidential debates and noting common challenges in teaching about them (e.g., limited political knowledge, strong partisanship). Shaping our analysis were two frameworks: (1) the Authentic Intellectual Work framework (Newmann, King, \& Carmichael 2009), which defines substantive conversation as reciprocal verbal exchanges about subject matter in the discipline that involves higher order thinking, such as applying ideas, making distinctions, and forming generalizations, and (2) the academic discussion framework of Elizabeth, Anderson, Snow, and Selman (2012), which emphasizes students' employment of evidence, logic, collaboration, and divergent 
perspectives. When assessing discussions about debates in order to identify key pedagogies and challenges, we considered these standards of quality.

Coding categories about students' engagement in discussions included political interest level (during interviews), content (during observations, with sub-codes on candidate competition, interpersonal dynamics, public policies) and interaction (opinion/impression, factual statement, evidence-based argument, authentic question, building on peer's comment, building on teacher's comment). Pedagogical themes included scaffolding preparation for discussion, encouraging partisanship, diffusing partisanship, shifting discussions topics, and focusing on strategy/competition. Drawing on these thematic codes, we wrote memos conceptually linking them to identify differences among classrooms and develop our claims. Then we revisited our data again, adjusted and combined some codes, and revised our claims to reflect these adjustments.

\section{Findings}

Our analyses indicate that discussing presidential debates was often, though not always, highly engaging for students. Teachers guided these discussions in a variety of ways. Although some required students to take notes on the debate and share ideas from their notes in class, others took a more spontaneous approach, showing video clips in class and asking specific questions. By comparing and contrasting teachers' pedagogies and classroom activity structures - and relating these to students' classroom behaviors and comments- we identify several experiences that appear to support students' participation in dynamic, substantive discussions of the debates. In our summary below, we have selected data exemplars that illustrate our broader findings. (Readers should note, 
however, that we share these exemplars to clarify our claims about students' experiences in discussions and not to provide representative portraits of particular teachers.)

\section{Students' engagement in discussing presidential debates}

Data from our observations and interviews indicate that in most classrooms, discussions of the debates were among the most dynamic events of the semester. For many student participants in this study, hearing candidates directly address each other helped them to appreciate the importance of the election and candidates' rationales for different policies. As Tom from Red Rock reflected, "I found it interesting just to see what they had to say about their ideas. ... Me and my dad watched them and I actually found them interesting" (Interview, November 16, 2012). Many student interviewees said that they would not have watched the debates if their teachers had not required it - but that they ultimately enjoyed it. Furthermore, several mentioned learning about issues that they had not considered before, such as foreign affairs and immigration. Although some students found watching the debates tedious, even these students indicated that knowing these events would be discussed in class prompted them to watch, which in turn made them want to learn more about the election.

Because debates often surfaced policy details and their underlying values, discussing these televised events gave students the chance to grapple with substantive issues. Brad from Red Rock said that post-debate discussions were much richer than typical political discussions at his school, which usually comprised simply dismissive or enthusiastic remarks about candidates:

When you discuss in class after you had to watch something then there areeveryone is informed and they can say, "I don't really like how Obama said he 
wanted to increase the tax rate and stop the-the Bush tax cuts and-and start spending more money on education. I think that they have enough money spent there now." And you're like-and then I say, "Well, I think education is important. We have all these problems right now that could be fixed with more financial aid." And then you start getting into real—real—real discussions, but usually the ones where people are ill-informed tend to not last very long just because there's nothing that you can discuss (Interview, November 27, 2012).

Several interviewees shared similar comments, indicating that the debates provided them and their classmates with vivid and important material to examine, which they may not have otherwise accessed. Whereas several students mentioned that they enjoyed seeing the conflict and 'fireworks' of the debates, most also acknowledged the value of hearing about a wide variety of national and international challenges.

Given many students' overall interest in the debates' content and dynamics, class discussions about them tended to elicit participation, but as we note below, the degree of interaction and content in these exchanges varied across classrooms and appears to have been bolstered through certain pedagogical strategies.

\section{Providing opportunities to openly explore issues}

When teachers provided forums for students to openly discuss issues that were salient to them in the debates, students appeared much more likely to engage in substantive, interactive exchanges. We observed several post-debate discussions in which teachers committed substantial class time (30 or more minutes) to ask open-ended questions and encourage students to share specific recollections from the debate, and these tended to be rich in content, as they enabled students to share their perspectives on the event - even if heavily laced with emotion and 
partisanship. On the other hand, in classes where teachers asked narrow questions and gave students limited time to discuss the debates, verbal exchanges often remained brief and superficial, with participants demonstrating a lack of engagement.

Indeed several teachers in this study held post-debate discussions that were quite cursory and did not provide students the chance to share what they had learned or explore their own or candidates' perspectives, and these usually fell flat. For example, after the first debate between Obama and Romney, Mr. Atherton from Blue Lake South spent the first thirty minutes of class screening a film about a previous mayoral election and then attempted to squeeze in a discussion about the debate in the last fifteen minutes of class. To start, he rapidly posed strategy-oriented questions, such as how to determine a debate's winner and the impact of flash polls. He gave students little time to discuss their ideas, and Mr. Atherton was forced to answer several of his own questions (Field notes, October 5, 2012). Similarly, in Mr. Kent's class at Red Rock after the final debate, the teacher screened portions of the debate and then allocated about seven minutes to debrief. In response to closed-ended questions (e.g., "Was it a slugfest?"), two students offered hesitant responses, seemingly unsure if there was a correct answer. Then, perhaps to fill the awkward silence, the teacher proceeded to offer his own interpretation of the debate:

Was this truly a debate? You know, if you know anything about the debate format, whether you've done it in high school or other places - Yeah, the arguments you're looking for, that's entertaining, but the more and more I see these, the less they seem like a debate.... The format that really defines a debate, with timing - I mean, if you're in forensics - Is anyone here in forensics? - If you're in forensics and you do a debate on 
the whole thing, timing matters. You lose points if you don't. Okay? You answer the question. Okay? And there's more control in the hands of the moderator.

Rather than guiding and probing students to share their own understanding of what had transpired, the teacher used the limited class time to express his own views (Field notes, October 23, 2012).

In contrast, when discussions around debates allowed students to explore ideas raised by the candidates, they were more engaged in classroom exchanges and demonstrated more interest in learning about the issues. Both CSEs at Blue Lake North reserved substantial time to review and discuss the issues raised in the debates (e.g., Field notes, October $5 \& 17,2012$ ). For example, after the second Obama-Romney debate, Mr. Kushner's class spent a full class period dissecting various issues - first sharing general observations and then examining candidates' claims by visiting fact-checking web sites and discussing what they learned from them. Kushner launched class that afternoon by asking simply, "What did you think? What were your initial reactions?" And as he listened, several students recalled moments from the debate that seemed significant to them, with Mr. Kushner offering occasional guidance and clarification:

Lindsay: That line at the bottom of the screen was so distracting. ... And it got really awkward when Romney would say things that were wrong - like that part about the terrorist attack[and Obama's comments the next day]. And Obama said to look at the transcript. It got so awkward.

Mr. Kushner: Anyone want to comment?

Ned: I like how the moderator said, 'Nooo, you're wrong.' [Laughter]

Mr. Kushner: What do you mean when you say it was awkward? 
Lindsay: Everyone knew he was wrong, but he insisted that he was right.

Mr. Kushner: There may be more to this story, but [seeing a student's hand and nodding to him], yeah.

Will: Another awkward moment was about the pensions.

Mr. Kushner: What happened with that? What is a pension?

Will: A retirement fund that you get from your job.

Mr. Kushner: So what was the awkward pension part?

Will: After Obama accused Romney of investing in Chinese companies, Romney said, 'You've invested in China, too.' . . It was very tense.

John: Then Obama said, 'Well, my pension's not as big as yours.'

[Laughter]

Mr. Kushner: So he made a joke.

Jane: I thought it was very tense the whole time - and immature. They were bashing each other the whole time and instead of answering the question, they'd go back to a question from before. It was very argumentative (Field Notes, October 17, 2012).

By first opening the floor to students' comments and occasionally interjecting clarifying questions, Mr. Kushner helped to surface students' perspectives and generate substantive interactions before guiding them through fact-checking work.

This next phase of class, involving small group work online, gave even more students opportunities to further examine candidates' statements, and several students said that they found it very useful and were surprised by the number of untruths spoken by candidates in the debate. Reflecting on this experience overall, Lashanna said, "I liked watching the debates. Like, honestly [and] then when we got into little small groups, and I actually knew what I was talking 
about, and felt confident in what I was talking about, [and] I could actually talk" (Interview, November 28, 2012). As in many settings, smaller groups can enable more people to express themselves.

Furthermore, when students had time to unpack what they had heard in the debates, they responded to one another's comments without having to be led directly by the teacher, grounding their arguments in evidence gathered directly from the debates. For example, in Ms. Galliano's class, the teacher began each postdebate discussion by screening a highlights reel and asking broad open-ended questions, such as: "Strong points for the president? Strong points for Governor Romney? Points where what they had to say really worked?” In response, students often shared their opinions of issues and candidates by referring to specific comments. One student mentioned that she found Romney's comments about women "offensive" - than instead of making exceptions for women, he should be committed to "equal pay for equal work." Three other students added to this, with one mentioning that Obama was stronger on women's rights because of his efforts to pass the Lilly Ledbetter Act and that "Romney didn't ever answer the question the way that I wanted him to.” Ms. Galliano allocated an entire class period for these discussions after every debate and repeatedly asked open-ended questions that encouraged students to refer directly to candidates' statements and positions, and this helped students practice making evidence-based arguments and building on their classmates' comments (Field notes, October 17, 2012). In interviews, students in the Blue Lake North CSEs indicated that discussing debates were a powerful experience for fostering their political engagement.

\section{Scaffolding students' preparation to discuss the debates}

Although allowing the time for quality classroom discussion was vital, providing guidance on how to prepare for analytical discussions of the debates also facilitated more 
substantive discussions. On the other hand, if students viewed only highlights of debates in class and were not required to consider related issues in advance, discussions often involved a small number of students and few political facts or evidence from the debates.

For example, at Red Rock, Mr. Kent did not require his students to watch the debates at home, and when he tried to stimulate discussions about them, there was often very little participation. After the third Obama-Romney faceoff, he screened some hastily selected debate segments (without presenting guiding questions), and the class discussion remained superficial and lethargic. In response to Mr. Kent's numerous questions, the vast majority remained silent. At one point, a student filled the void by remarking that "they [candidates] went off topic a lot," and later another said the candidates' policy plans "didn't achieve details" (Field notes, October 23, 2012). Although students' lack of participation may have been related to Mr. Kent's limited follow-up questions, the teacher may have hesitated to press students who seemed unprepared. Indeed, he considered this class to be "comatose" (Interview, December 13, 2012), but this may have been due in part to limited scaffolding. When students were not prepared for discussion and did not purposefully watch debates, teachers often asked simpler questions and even answered those questions themselves, and it simply was not possible for students to have collaborative, evidence-based exchanges to deepen their understanding of the issues.

On the other hand, in classrooms where students were required to answer questions regarding specific issues raised in debates before discussions occurred, classroom exchanges were lively and covered more substantive issues. For example, Mr. Kushner at Blue Lake North asked students to prepare for discussion by watching the debates for homework and completing a worksheet that solicited their perceptions of the most important issues raised in the debate, candidates' positions on those issues, and candidates' honesty. The form had designated spaces 
for students to write the candidates' positions on healthcare, employment, and tax policy as well as charts where they could rate - and justify their ratings of - each candidate's integrity, vision, and knowledge of the country. After coming to class with these forms mostly filled out, students appeared equipped to explore the nuances of issues that interested them. In their post-debate discussion, students raised a variety of authentic questions, focusing especially on candidates' differing perspectives on the role of the federal government in providing a social safety net. They also noted that certain issues they cared about, such as abortion and environmental concerns, were not raised in the debate and that they hoped to see these addressed in the next one (Field notes, October 4, 2012).

Several other teachers also required students to prepare in advance to discuss the substance of the debates. For each debate, Ms. Allen at Red Rock asked all students to watch the event and fill out a three-by-four grid worksheet, which had three labeled columns across the top - one for major questions asked (by the moderator or audience members) and one for each candidate - and then three rows beneath, in which students could note what they considered to be the most important questions of the debate and how each candidate responded (see Appendix A). When students came to class the following day, they were prepared to share details of what they had heard in the debate, and discussions were both substantive and dynamic because each student had chosen a unique set of issues based on their interests. After the first debate, for example, students were assigned to discuss ideas in groups of "likeminded" (ideologically similar) students, and exchanged ideas and questions about a variety of topics, such as tax cuts, healthcare, and the Simpson-Bowles deficit reduction plan. In these small groups, students had different roles - recorder, task master, devil's advocate, and tech master (to find debate clips online) - and this structure appeared to help students begin sharing their opinions of candidates' 
statements and addressing each other's comments. Indeed nearly every student in the class appeared to be engaged during these small group meetings - either sharing comments or attentively listening (Field notes, October 5, 2012).

Following a different structure, Mr. Atherton asked students to watch the second presidential debate for homework and identify "hot topics, techniques of persuasion, favorite phrases, rehearsed responses, and cutaways" (Field notes, October 16, 2012). In class the next day, students referred to their prepared notes to cite the candidates' comments and behaviors, including their remarks on oil prices, assault weapons, and job creation, as well as their treatment of the moderator. For example, one student recalled, "In Obama's response to the oil question, he mentioned America's natural resources, the expansion of drilling, but he didn't mention gas prices" (Field notes, October 17, 2012). Several students also brought up candidates' demeanor, but the questions they had addressed for homework appeared to help them focus on the policy issues under discussion.

Atherton was encouraging of students' comments and regularly offered extended responses with background information about the topic. At one point during class, for instance, he spent two minutes explaining common critiques of Romney's pension investments and the ways that pension investments typically occur. While these may have been informative, they were often met with silence and may have limited students' interactions with each other. Nonetheless, preparing in advance for discussion allowed participants to make evidence-based arguments, raise substantive issues, and effectively share their perspectives with their peers.

\section{Shifting engagement in the "horse race" to engagement in substantive issues}

In some postdebate discussions, students enthusiastically mentioned competitive and interpersonal debate dynamics. Although a few of these comments were rich in social studies 
content, such as the quality of polling, many focused on evaluating candidates' performance and personality. Some teachers were able to leverage this engagement towards more substantive, sustained explorations of issues. However, when teachers did not use such comments as springboards towards evidence-based analysis, the discussions often remained focused on students' general opinions and impressions of who won or lost the debate.

For example, after the Vice Presidential debate, Mr. Bristol at Centerville launched a discussion by asking about the performance of the candidates and the moderator, and students proceeded to share their impressions of the event without commenting on any policy issues. Although one student commented, "I think she [the moderator] favored Biden, but that is okay because I like him," another said, "I like Ryan better than Romney. He isn't a kiss-up, has the emotion behind it." Later a student explained her impression of Ryan as "canned” while a different student called Biden “very rude.” Instead of asking students to specify how candidates' behaviors or ideas shaped these impressions - or how candidates' qualities might affect their work in office, Mr. Bristol encouraged students to continue offering opinions without examples, which they did:

Stephanie: They kept interrupting each other.

Mr. Bristol: They kept interrupting each other. Did you get the sense that they like each other?

Janice: No. It's funny. They kept saying, "My friend."

Mr. Bristol: That's something politicians do a lot. They'll say 'My friend from across the aisle.' I think Biden said it a lot. Another take-away? .. . Was it a brawl? Was it a draw? Jen: I don't think it was a draw. Ryan kept avoiding the question and letting himself get interrupted. 
Mr. Bristol: So you think he should have been more forceful.

Jen: Yeah.

Mr. Bristol: So who won then?

Jen: Biden won.

Mr. Bristol: How many of you thought that Biden won? [Hands go up.] How many of you thought that Ryan won? [Hands go up.] How many of you thought it was a tie?

[Hands go up.]

Mr. Bristol: Other take-aways? [Two students respond at once.] . . . You didn't like the moderator? Why not?

Erin: I don't know. She just didn't seem like somebody I'd like.

Mr. Bristol: Yeah. Did anybody like her?

After further exchanges about the interpersonal dynamics of the debate, Mr. Bristol proceeded to explain how the media develop their opinions of who won or lost a debate (Field notes, October 12, 2012). Later, after watching some video clips from the debate, students briefly listed a few policy issues they considered important, but with few exceptions, the discussion remained impressionistic, as if students had watched a program primarily for entertainment.

In contrast, some teachers effectively leveraged students' attention to candidates' debate behavior to encourage engagement with the issues, asking them to relate their observations to candidates' positions. In Mr. Robinson's class at Red Rock, when the first comment about the debate was broad criticism of the candidates, he set a tone and a standard for discourse by urging the student to be more specific:

Ed: I don’t like ‘em. Romney or Obama.

Mr. Robinson: Specifically what did they say? 
Ed: I can't remember exactly because I was so angry.

Mr. Robinson: Provide some specifics from the debate.

Ed: Well, apparently he wants to cut PBS because it's like on public funding. Like we shouldn't be paying for that, I guess.

Mr. Robinson: Who said that?

Ed: Romney.

Mr. Robinson: In what way? [Jared raises hand, and Robinson looks at him.] Go ahead.

Jared: Romney thinks we should cut government spending on programs that he think don't qualify, like PBS and other programs that get funding.

Fred: What about [children's cartoon] Caillou?

[Laughter.]

Gina: Another thing that he said was that we move a lot of government funding to the state and local level, like health care. He thinks that would be better handled by each state.

Mr. Robinson: What do you guys think about that?

This led to content-rich comments on a vast number of issues, including not only health care but also education, green energy, and tax cuts (Field notes, October 5, 2012).

Discussions of the debates in Ms. Galliano's class at Blue Lake North, where students overwhelmingly favored Obama, often involved heated rhetoric that she regularly curbed towards substantive discussions. In one postdebate discussion, when students began opining about debate's dynamics, Ms. Galliano steered it back to political content:

Alice: When she fact-checked Romney on the Libya thing, that was weird, but I also wondered why she didn't do it more. 
Nolan: Maybe she [the moderator] was pissed because Romney kept cutting her off. He cut her off in a rude way.

Ms. Galliano: What is the deeper issue with Libya? Does anyone want to explain?

Nolan: The US embassy in Libya was attacked, and the ambassador was killed. Romney keeps bringing it up because Obama failed to protect us, so how will he do it in a national emergency like $9 / 11$ ?

Ms. Galliano: Ambassador deaths are a big deal. Maybe the American public doesn't make the distinction because we are at war, but his murder is a big deal to the political elite and shows the failure of the commander-in-chief.

After this, the conversation moved to other foreign policy issues, such as the candidates' positions on Israel (Field notes, October 17, 2012). Although Ms. Galliano allowed students some time to consider how candidates presented themselves and regarded each other, she was careful that most of the discussion focused on larger policy issues. She explained that this was not always easy but central to her pedagogical purpose:

They [students] are really interested in the horse race kinds of issues and, you know, that's a distraction in the end. Because really it's sort of the issues that matter, not who is up in the polls in Ohio today.... [It's important to] be fair and try to clarify the policy differences between the two, their substantive, meaningful policy differences, which is probably most important for students to understand (Interview, November 1, 2012). Ms. Galliano, in her effort to strengthen students' understanding of the candidates' positions, put these ideas into practice by asking questions that required students to cite evidence of candidates' policy positions - and sharing her own relevant content knowledge when students appeared uninformed (or misinformed) on particular issues. 


\section{Broadening students' views beyond partisan perspectives}

Some students in this study appeared to view presidential debates through a partisan lens, more attentive to the "points" won by their favored candidates than to the issues or facts under consideration. This was especially problematic in certain classrooms where an overwhelming majority of students aligned with one particular party. Although some teachers in these settings facilitated (often unintentionally) the reinforcement of partisanship, others were able to broaden students' perspectives by enacting specific strategies, such as playing devil's advocate, explicitly presenting opposing viewpoints, and supporting critical classroom discussion.

Several postdebate discussions involved teachers relying heavily on students' general opinions, with few follow-up questions targeting rationales or policy ideas. In Mr. Robinson's classroom at Red Rock, some of these served as forums for students to express their views but not necessarily consider differing perspectives. After the first debate between Romney and Obama, for example, students came to class prepared to share points they liked in the debate, but they were rarely asked by peers or their teacher to consider new perspectives on the issues they raised. One student cited Romney's point "that Obama spent millions on green energy and that those businesses went out of business - and that that money could have been spent on education." Afterwards, her peers did not respond, and rather than asking or inviting students to ask a follow-up question, Mr. Robinson appeared to seek a topic change, asking the class if they wanted to share other comments on the debate. Throughout the discussion, the series of comments was strongly proRomney, with students largely echoing the Republican candidate's critiques of the president's policies on the federal debt, health care, and other issues. When one student 
asked how the candidates had described their approaches to the national debt, Mr.

Robinson redirected the question to the students, who offered these comments:

Pam: Romney was saying how we need to lower federal spending to, like, encourage economic growth and wants to eliminate Obamacare and create more programs at the state level. He also wanted to save money by cutting back on government programs and condensing the employees in government. Maris: I kind of felt like Obama just blamed Bush for our debt. And he said he didn't really do anything wrong - that he helped the economy. Yet our debt is higher than ever, so I don't really understand why he said he didn't do anything wrong. James: I thought it was interesting how they responded to questions about how they'd take on the debt. Romney explained it and had a plan, and Obama just said he had a four trillion dollar tax cut but didn't want to explain it. It was, like, available online.

In this exchange, students were indeed building on one another's comments, but they were sharing recollections primarily of only one side of the debate. Meanwhile, in a more ideologically diverse class at Red Rock, Ms. Allen seemed to be intentionally avoiding partisan clashes by arranging students in politically homogenous groups to discuss the first debate, making it difficult for them to talk across party lines (Field notes, October 5, 2012). At Blue Lake South, discussion of the second Obama-Romney faceoff was also highly partisan, largely consisting of students recounting Obama's strong moments and Romney's weaknesses. For instance, after Melvin began the discussion by exclaiming, "Obama kicked ass!", another student smiled as she described enthusiastically how skillfully the president had ended the debate: "I think [Obama] used his closing statement to his advantage by 
throwing in the 47 percent because [Romney] had nothing else to say after that." Shortly thereafter, another student mocked Romney's effort to malign the Democrat for his pension investments (Field notes, October 17, 2012). Although Mr. Atherton occasionally interjected to provide background information about certain issues, he rarely clarified the rationale for the Republican candidate's positions. Reflecting on discussions, Blue Lake South student Andrew acknowledged his limited exposure to differing views:

[I]n some ways, I do kind of feel like I'm missing part of it and but, even if it's not going to make me think differently, I should at least know about it and be able to be like, oh, understand why you think this and that, so. Then-but yeah, that's kind of missing now" (Interview, November 13, 2012).

Andrew's comments demonstrate an unrequited desire to have his perspectives challenged and develop a better understanding of different political viewpoints. Indeed Mr. Atherton himself expressed frustration with students' one-sidedness and unwillingness to consider opposing viewpoints (Interview, December 19, 2012). During observations, he occasionally played devil's advocate to introduce different perspectives, but these comments tended to be quite brief (Field notes, October 5, 11, 17, 19, 23, and 31, 2012).

Some teachers, however, were able to meaningfully challenge students' partisan perspectives. At Blue Lake North, Mr. Kushner regularly challenged students to consider opposing viewpoints. The vast majority of his students strongly identified as Obama supporters, so in order to help students be more open to Romney's position, Mr. Kushner purposefully worked to humanize the Republican. Mr. Kushner explained, "When kids wanted to bring up negative stuff - and they did often, I said, 'We're talking positive things now.' ... So I do things like that to try to balance this out. Bringing in Romney's death 
penalty plan shows that he thought about it and tried to make it work" (Interview, October 12, 2012).

After the first Obama-Romney debate, Mr. Kushner demonstrated his commitment to assisting his left-leaning students to engage with the substance of Romney's ideas. After students took shots at Romney's statements on welfare, Mr. Kushner provided more background:

His larger point was that we've become a society that keeps giving stuff out and instead of having people become self-reliant, they keep getting stuff. And whenever you get stuff, it's hard to stop getting it. You feel like you deserve it after a while, right? You feel like it's owed to you ... Governor Romney is saying that we have to get people off the idea that stuff is owed to them and get them to do it themselves. And then you have all that energy and creativity and self-reliance.... Romney says that before the welfare state, people used to live with their families and take care of them. Now, people want government to do it. That's the argument (Field notes, October 4, 2012).

By fleshing out Romney's position without explicitly promoting it, Mr. Kushner challenged the apparent consensus in the room, made space for more conservative students to share their views, and ultimately generated a discussion that included more diverse voices. After the above comments, two students who had not spoken earlier in the discussion expressed their belief that Romney had performed well in the debates by attacking Obama's record.

Looking back at the class as a whole, including discussions of debates, senior Gabrielle appreciated how Mr. Kushner regularly helped expand the perspectives of students in a politically homogenous environment: 
I think what I liked the most is how Mr. Kushner would start out by trying to have a discussion. Similar people would speak and mostly have the same opinions and then we'd watch a documentary or read articles and then he'd open up the conversation again and people, I think, would all of a sudden feel more confidence to speak out because they were more knowledgeable and had learned a different side to things... . There were moments where I would hear the other side and say, "Oh, look. I understand that. I never understood that argument before. I never could connect with it at all." And even if I disagreed with it still, it was still really enlightening for me to see that the other side was often times just as valid as mine or just as supported as mine (Interview, February 8, 2013).

As for many of her classmates, Gabrielle's experiences in Mr. Kushner's class had helped her to consider different perspectives and in the process appreciate the value of logical arguments that she had not previously heard.

\section{Discussion}

Our findings indicate that presidential debates provide powerful opportunities for educators to foster dynamic, substantive discussions of political issues but that guiding these experiences towards these ends can be challenging. When asked simply to watch debates and talk about them, some students may hesitate to share their thoughts at all or, instead of considering the public policy issues at stake, focus on interpersonal dynamics or who appeared to "win." In the process, these exchanges can quickly become highly partisan or polarized. As instructional gatekeepers (Thornton 1989), some educators may opt to avoid these challenges by severely limiting such discussions, as they do with other potentially contentious issues (Hess 2004). However, this study suggests that by offering 
sufficient scaffolding, questioning, and guidance, and fostering an open classroom environment, teachers can leverage students' interest in the debates' relevant content to help them engage in more substantive analyses.

Building on the findings from this study and prior research, here we present a framework for how educators can generate thoughtful classroom discussions of political debates (see Figure 1), and this framework could also be useful for discussions of other current events or social issues. We suggest strategies that are rooted in three central principles: (a) authentic, purposeful questions, (b) open classroom climate, and (c) scaffolded preparation. Moreover, when these strategies are combined by educators with strong underlying democratic and civic learning purposes, we expect that these elements can create Dynamic Substantive Democratic (DSD) Discussions, which can enable students to thoughtfully examine important issues while meeting other valuable educational goals, such as developing deliberation skills and knowledge of public issues. 


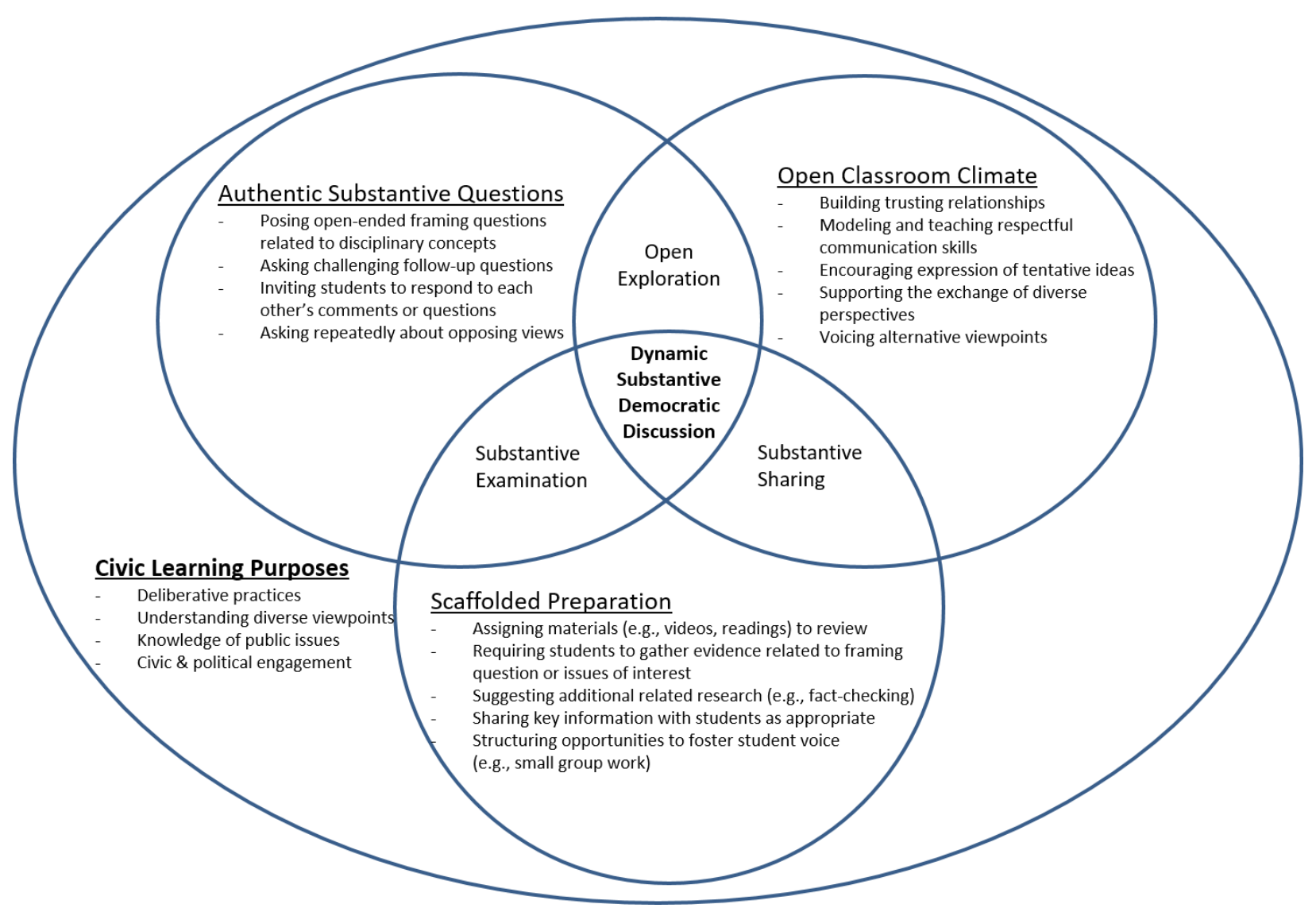

Figure 1. Conceptual framework for teaching with Dynamic Substantive Democratic (DSD) discussions

As data from this study indicate, classroom discussions are much richer when students have had opportunities to prepare to share relevant ideas. Although some teachers may require preparation to be done at home, others may allocate class time. To encourage the consideration of alternative views or certain background material, some teachers also may find it useful to engage in some direct instruction, as Mr. Kushner did when he presented Romney's perspective. Indeed, there are many ways to help students prepare to fruitfully exchange ideas about controversial public issues. Some organizations, such as the National Issues Forum Institute (2016), have developed issue guides that 
provide in-depth information on distinct policy options for addressing specific public problems (e.g., economic growth, climate change), and these can be useful in scaffolding issue-oriented discussions in classrooms and communities.

To prepare to discuss political debates that examine a number of issues, one increasingly useful avenue is fact-checking Web sites, which can facilitate evidence-based discussions as well as the assessment of candidates' truthfulness. Furthermore, given how wide-ranging such debates can be - and the challenge of keeping students focused on a single issue for very long- it may be valuable to ask students to identify an issue or two from the debate on which to conduct further research to share with their peers. Regardless of the sources or specific tasks educators suggest, providing students a chance to gather and think about information in advance, especially with the support of purposeful guiding questions (that will be central during in-class discussion) and peers, can help prepare them to participate more actively and substantively in classroom exchanges.

Second, establishing an open classroom climate can be vital for fostering the productive exchange of diverse perspectives. Prior research indicates that when students feel free to share ideas and believe that different viewpoints will be respected, they experience numerous civic benefits, including greater perspective-taking and tolerance (Avery et al. 1992, 2014), civic knowledge (Campbell, 2008), and critical consciousness (Godfrey \& Grayman, 2014). Indeed, in environments where individuals openly express themselves, students may have more opportunities to share newly emerging, tentative ideas; hear their peers' views; challenge their prior conceptions; and build novel understandings. Evidence from our study above suggests that one-sided partisan perspectives can dominate classroom discussions but that educators can take steps to 
address this, such as asking students to elaborate differing viewpoints or voicing compelling alternative arguments themselves. Although segregating students into likeminded groups, as Ms. Allen did, can create a safe space for the initial expression and clarification of ideas, regularly maintaining such arrangements can limit students' learning about diverse perspectives and boundary crossing. In some settings the context of a heated election can make discussions involving divergent viewpoints difficult, but an open classroom climate can develop over time through trusting relationships, collaborative leadership, and democratic practices - and can be quite valuable for students' collaborative learning (Narvaez, 2010).

In addition, authentic substantive questions can help to frame discussions and to affect their trajectory in ways that challenge and expand students' understanding of the issues at hand. Substantial prior research has examined and confirmed the tremendous potential of purposeful, thoughtful teacher questioning and students questioning one another (Nystrand et al., 2003), and our findings provide more evidence for this. Indeed, vigorous, multiactor questioning can generate dynamic, robust exchanges, and beginning discussion with a clear open-ended question, as Ms. Galliano and Mr. Kushner did, can generate students' initial participation that teachers and peers can then build upon with substantive follow-up questions (Author and Colleagues 20xx). On the other hand, overly narrow questions - though potentially useful in a rapid-fire exchange - may at the outset of a discussion discourage students from participating if they do not know the answers, as Mr. Kent and Mr. Atherton in this study experienced.

Although open-ended framing questions can be valuable for fostering participation, we also found that the specific content of such questions can, of course, affect the 
discussion's substance - perhaps diverting it from or toward disciplinary concepts or opposing perspectives. Exploring non-disciplinary concepts or one strongly worded opinion may stimulate students' initial interest, and this can be worthwhile, especially in settings where such engagement is rare. But to broaden students' thinking, as several educators in this study demonstrated, skillful questioning strategies can shift discussions away from such issues and towards more central civic learning goals, such as understanding multiple perspectives on public issues (Torney-Purta, Cabrera, Roohr, Liu, and Rios 2015). Indeed, maintaining clear purposes for discussion can be essential for consistently monitoring, guiding, and bolstering its content.

Indeed, teachers employing the elements of the DSD discussion framework will inevitably face dilemmas - as all teachers do when navigating and selecting content, designing learning experiences, and building classroom community. One key pedagogical question for leading discussions of political debates and other topics concerns what exactly constitutes a substantive, worthwhile issue. Although state standards, textbooks, and colleagues may offer some guidance, the rapid development of current events and policy questions often lay responsibility of content selection with individual teachers. When educators are uncertain, we argue, they should consider what content is and/or will be important for their students to understand as they navigate the world around them and how seemingly narrow topics, such as tax policy or police body cameras, might be manifestations of ongoing standards-related content, such as the role of government (as Mr. Kushner demonstrates above) or the history of race relations. Another complex decision for educators is how much time to allocate to different issues, and this can be especially challenging in discussions of extended political debates. If one debate surfaces 
15 different issues, for example, should a post-debate discussion aim to address all of them, half of them, or perhaps just one underlying issue? In this situation, educators, as usual, will have to choose between or appropriately balance breadth and depth - and help to ensure that their students are prepared accordingly.

Whereas the DSD discussion framework can be useful for educators interested in fostering powerful, interactive exchanges about public issues, it is important for researchers, including teacher-researchers, to continue exploring questions in this domain. For example, how do educators learn to use this framework, and what are its challenges and affordances? Although many studies have documented teachers' strategies leading discussions (e.g., Hess 2009), little research has examined how these pedagogical skills develop.

In addition, above we highlight the importance of helping students prepare for discussions, but there has been limited research on how different types of preparation could spur different types of discussions. Whereas some scholars have examined how students learn democratic discussion skills (Flynn 2009) and others have detailed certain strategies for preparing students (Brookfield and Preskill 2012), little research has focused on how different strategies (e.g., fact-checking debates versus analyzing candidates' spoken words) could yield different types of results. In addition, whereas the present paper examined how students and teachers in seven classrooms explored presidential debates, it would also be worthwhile to compare classroom explorations of other high-profile public events, such as a gubernatorial election, a historical holiday (e.g., "Columbus Day"), or an anniversary of 9/11. Examining similarities and differences across settings could provide insights about the state of civic learning, the challenges involved in this work, and how it 
may be done differently. In the process, researchers could examine the extent to which teachers' disclosure of their own viewpoints influences discussion and students' learning (Hess 2009; Washington and Humphries 2011).

As researchers and scholars have long argued, discussing controversial public issues can be vital for the civic learning of young people. By bringing together a diverse crosssection of individuals, schools and classrooms offer unique settings for encountering a variety of people and ideas that can enrich and complexify students' conceptions of the world. Political debates, including those during the presidential election season, often involve the presentation of competing values and policy plans on numerous issues and can therefore provide rich fodder for discussion. Given the heated nature of such debates, guiding these discussions can be challenging, and we hope that the DSD discussion framework can help educators to generate substantive exchanges in which students thoughtfully and openly explore significant issues with their peers. 


\section{References}

Applebee, Arthur N., Judith A. Langer, Martin Nystrand, and Adam Gamoran. 2003.

"Discussion-based approaches to developing understanding: Classroom instruction and student performance in middle and high school English." American Educational Research Journal 40, no. 3: 685-730.

Avery, Patricia G., Karen Bird, Sandra Johnstone, John L. Sullivan, and Kristina Thalhammer. 1992. "Exploring political tolerance with adolescents." Theory \& Research in Social Education 20, no. 4: 386-420.

Avery, Patricia G., Sara A. Levy, and Annette MM Simmons. 2014. "Secondary students and the deliberation of public issues." PS: Political Science \& Politics 47, no. 04: 849-854.

Bickmore, K. 1993. Learning inclusion/including in learning: Citizenship education for a pluralistic society. Theory and Research in Social Education, 21(4), 341-384.

Brice, Lynn. 2002. "Deliberative discourse enacted: task, text, and talk." Theory \& Research in Social Education 30, no. 1: 66-87.

Campbell, David E. 2008. Voice in the classroom: How an open classroom climate fosters political engagement among adolescents. Political Behavior, 30(4). 437-454.

Coffey, Daniel J., William J. Miller, and Derek Feuerstein. 2011. “Classroom as reality: Demonstrating campaign effects through live simulation." Journal of Political Science Education 7, no. 1: 14-33.

Condon, Meghan. 2015. “Voice lessons: Rethinking the relationship between education and political participation." Political Behavior 37, no. 4: 819-843.

Costello, Maureen B. 2016. Teaching the 2016 Election: The Trump Effect. Southern Poverty 
Law Center. Available online at https://www.splcenter.org/20160413/trumpeffect-impact-presidential-campaign-our-nations-schools

Day, Jonathan, Keith Boeckelman, Casey LaFrance, Richard Hardy, and David Rohall. 2012. "Stimulating civic engagement through a mock presidential election." National Civic Review 101, no. 2: 34-37.

Deveci, Handan. 2007. “Teachers' views on teaching current events in social studies." Educational Sciences: Theory \& Practice 7, no. 1: 446-451.

Dewey, John. 1915. Democracy and Education. Ontario, Canada: Collier-Macmillan.

Dewey, J. 1933. How we think: A restatement of the relation of reflective thinking to the educative process. Boston: Houghton Mifflin.

Elizabeth, Tracy, Trisha L. Ross Anderson, Elana H. Snow, and Robert L. Selman. 2012. "Academic discussions an analysis of instructional discourse and an argument for an integrative assessment framework." American Educational Research Journal 49, no.6: $1214-1250$.

Engle, Shirley H. and Anna S. Ochoa (2007). Education for Democratic Citizenship: DecisionMaking in the Social Studies. New York: Teachers College.

Flynn, Nora. 2009. "Toward democratic discourse: Scaffolding student-led discussions in the social studies." The Teachers College Record 111, no. 8: 2021-2054.

Glaser, Barney G., and Anselm L. Strauss. 1967. The discovery of grounded theory: Strategies for qualitative research. Piscataway: Transaction Publishers.

Godfrey, Erin B., and Justina Kamiel Grayman. 2014. "Teaching citizens: The role of open classroom climate in fostering critical consciousness among youth." Journal of Youth and Adolescence 43, no. 11: 1801-1817. 
Gutmann, Amy, and Dennis F.Thompson. 1998. Democracy and Disagreement. Cambridge: Belknap Press.

Haas, Mary E., and Margaret A. Laughlin. 2000. “Teaching Current Events: Its Status in Social Studies Today." Paper presented at the Annual Meeting of the American Educational Research Association (New Orleans, LA, April 24-28, 2000). ERIC, EBSCOhost (accessed June 3, 2016).

Haas, Mary E., \& Laughlin, Margaret A.. 2000. Teaching current events: Its status in social studies today. Paper presented at the Annual Meeting of the American Educational Research Association, New Orleans, LA.

Haas, Mary E., and Margaret A. Laughlin. 2002. "Teaching the 2000 election: A K-12 survey." Journal of Social Studies Research 26, no. 2: 20-30.

Hahn, Carole H. 1996. Research on issues-centered education. In Evans, Ronald W. and David W. Saxe (Eds.), Handbook on Teaching Social Issues. Washington, DC: National Council for the Social Studies.

Hess, Diana E. 2002. "Discussing controversial public issues in secondary social studies classrooms: Learning from skilled teachers." Theory \& Research in Social Education 30, no. 1: 10-41.

Hess, Diana E. 2004. “Controversies about controversial issues in democratic education." PS: Political Science and Politics 37(2), 257-61.

Hess, Diana E. 2008. Controversial issues and democratic discourse. In Levstik, Linda S. and Cynthia A. Tyson (Eds.), Handbook of Research in Social Studies Education. New York: Routledge.

Hess, Diana E. 2009. Controversy in the classroom: The democratic power of discussion. New 
York: Routledge.

Hess, Diana E., and Paula McAvoy. 2015. The political classroom: Evidence and ethics in democratic education. New York: Routledge.

Hess, Diana, and Julie Posselt. 2002. "How high school students experience and learn from the discussion of controversial public Issues." Journal of Curriculum and Supervision 17, no. 4: 283-314.

Johnston, J., E. Anderman, L. Milne, L. Klenk, and D. Harris. 1994. "Improving civic discourse in the classroom: Taking the measure of Channel One." Research Report 4. Ann Arbor, MI: Institute for Social Research, University of Michigan.

Journell, Wayne. 2011a. "Teachers' controversial issue decisions related to race, gender, and religion during the 2008 Presidential Election." Theory \& Research in Social Education 39, no. 3: 348-392.

Journell, Wayne. 2011b. "Teaching politics in secondary education: Analyzing instructional methods from the 2008 Presidential Election." The Social Studies 102, no. 6: 231241.

Journell, Wayne, Melissa Walker Beeson, and Cheryl A. Ayers. 2015. "Learning to think politically: Toward more complete disciplinary knowledge in civics and government courses." Theory \& Research in Social Education 43, no. 1: 28-67.

Kuş, Zafer. 2015. "Science and social studies teachers' beliefs and practices about teaching controversial issues: Certain comparisons." JSSE-Journal of Social Science Education 14, no. 3: 84-97.

Levy, B. L. M. 2011. Fostering cautious political efficacy through civic advocacy projects: A 
mixed methods case study of an innovative high school class. Theory \& Research in Social Education, 39(2), 238-77.

Levy, B. L. M. 2013. An empirical exploration of factors related to adolescents' political efficacy. Educational Psychology, 33(3), 357-390.

Levy, B. L. M. 2016. Which candidate should we elect and why?: An inquiry approach to teaching about elections. Social Education, 80(4), 201-205.

Levy, B. L. M., Solomon, B. G., \& Collet-Gildard, L. 2016. Fostering political interest among youth during the 2012 presidential election: Instructional opportunities and challenges in a swing state. Educational Researcher, 45(9), 483-95.

McDevitt, Michael, and Spiro Kiousis. 2006. "Experiments in Political Socialization: Kids Voting USA as a Model for Civic Education Reform," CIRCLE Working Paper 49, Center for Information and Research on Civic Learning and Engagement (CIRCLE), University of Maryland. https://ia600207.us.archive.org/3/items/ERIC_ED494074/ERIC_ED494074.pdf (accessed June 9, 2016).

Mercer, Neil, Rupert Wegerif, and Lyn Dawes. 1999. “Children's talk and the development of reasoning in the classroom." British Educational Research Journal 25, no. 1: 95111.

Narvaez, Darcia. 2010. “Building a sustaining classroom climate for purposeful ethical citizenship. In International Research Handbook on Values Education and Student Wellbeing, ed. Terence Lovat, Ron Toomeny, and Neville Clement, 659-673, Springer. National Council for the Social Studies (NCSS). 2013. "The College, Career, and Civic Life 
(C3) Framework for Social Studies State Standards: Guidance for Enhancing the Rigor of K-12 Civics, Economics, Geography, and History," Silver Spring, MD: NCSS. http://www.socialstudies.org/system/files/c3/C3-Framework-for-SocialStudies.pdf (accessed June 9, 2016).

National Issues Forum Institute (2016). Newest issue guides. Available online at https://www.nifi.org/en/nifi-materials

Newmann, Fred M., M., Bruce King, and Dana L. Carmichael. 2007. "Authentic instruction and assessment: Common core standards for rigor and relevance in teaching academic subjects." Iowa Department of Education. https://www.centerforaiw.com/wp-content/uploads/2016/05/authenticinstruction-assessment-bluebook.pdf (accessed June, 9, 2016).

Newmann, Fred M., M., Bruce King, and Dana L. Carmichael. 2009. “Teachign for authentic intellectual work: Standards and scoring criteria for teachers' tasks, student performance, and instruction. Itasca Books.

Nystrand, Martin, Adam Gamoran, Robert Kachur, and Catherine Prendergast. 1997. Opening dialogue. New York: Teachers College, Columbia University.

Nystrand, Martin, Lawrence L. Wu, Adam Gamoran, Susie Zeiser, and Daniel A. Long. 2003. "Questions in time: Investigating the structure and dynamics of unfolding classroom discourse." Discourse Processes 35, no. 2: 135-198.

Ochoa-Becker, Anna S. 1996. Building a rationale for issues-centered education. In Evans, Ronald W. and David W. Saxe (Eds.), Handbook on Teaching Social Issues. Washington, DC: National Council for the Social Studies.

Ochoa-Becker, Anna S. 2007. Democratic education for social studies: An issues-centered 
decision making curriculum. IAP.

Parker, Walter C. 2001. Classroom discussion: Models for leading seminars and deliberations. Social Education 65, no. 2.

Parker, Walter C. 2006. "Public discourses in schools: Purposes, problems, possibilities." Educational Researcher 35, no. 8: 11-18.

Passe, Jeff, \& Ronald W. Evans. 1996. Discussion methods in an issues-centered curriculum. In Evans, Ronald W. and David W. Saxe (Eds.), Handbook on Teaching Social Issues (pp. 81-88). Washington, DC: National Council for the Social Studies.

Patton, Michael Quinn. 1990. Qualitative evaluation and research methods . Thousand Oaks: SAGE Publications, Inc.

Rossi, John Allen. 1995. "In-depth study in an issues-oriented social studies classroom." Theory \& Research in Social Education 23, no. 2: 88-120.

Shaver, James P. 1992. Rationales for Issues-Centered Education. The Social Studies 83(3), 95-99.

Smith, Michelle K., William B. Wood, Wendy K. Adams, Carl Wieman, Jennifer K. Knight, Nancy Guild, and Tin Tin Su. 2009. "Why peer discussion improves student performance on in-class concept questions." Science 323, no. 5910: 122-124.

Strauss, Anselm, and Juliet Corbin. 1998. Basics of Qualitative Research: Techniques and Procedures for Developing Grounded Theory. $2^{\text {nd }}$ ed. Thousand Oaks: SAGE Publications, Inc.

Thornton, S. J. (1989). Aspiration and practice: Teacher as curricular-instructional 
gatekeeper in social studies. Paper presented at the Annual Meeting of the American Educational Research Association, San Francisco, CA.

Torney-Purta, J., Cabrera, J. C., Roohr, K. C., Liu, O. L., \& Rios, J. A. 2015. Assessing civic competency and engagement in higher education: Research background, frameworks, and direction for next-generation assessment. Princeton, $\mathrm{NJ}$ : Educational Testing Service.

Washington, Elizabeth Yeager, and Emma K. Humphries. 2011. "A social studies teacher's sense making of controversial issues discussions of race in a predominantly white, rural high school classroom." Theory \& Research in Social Education 39, no. 1: 92114.

Wells, Gordon, and Rebeca Mejía Arauz. 2006. "Dialogue in the classroom.” The Journal of the Learning Sciences 15, no. 3: 379-428. 


\section{APPENDIX A}

Mockup of Debate Worksheet Given to Red Rock Students

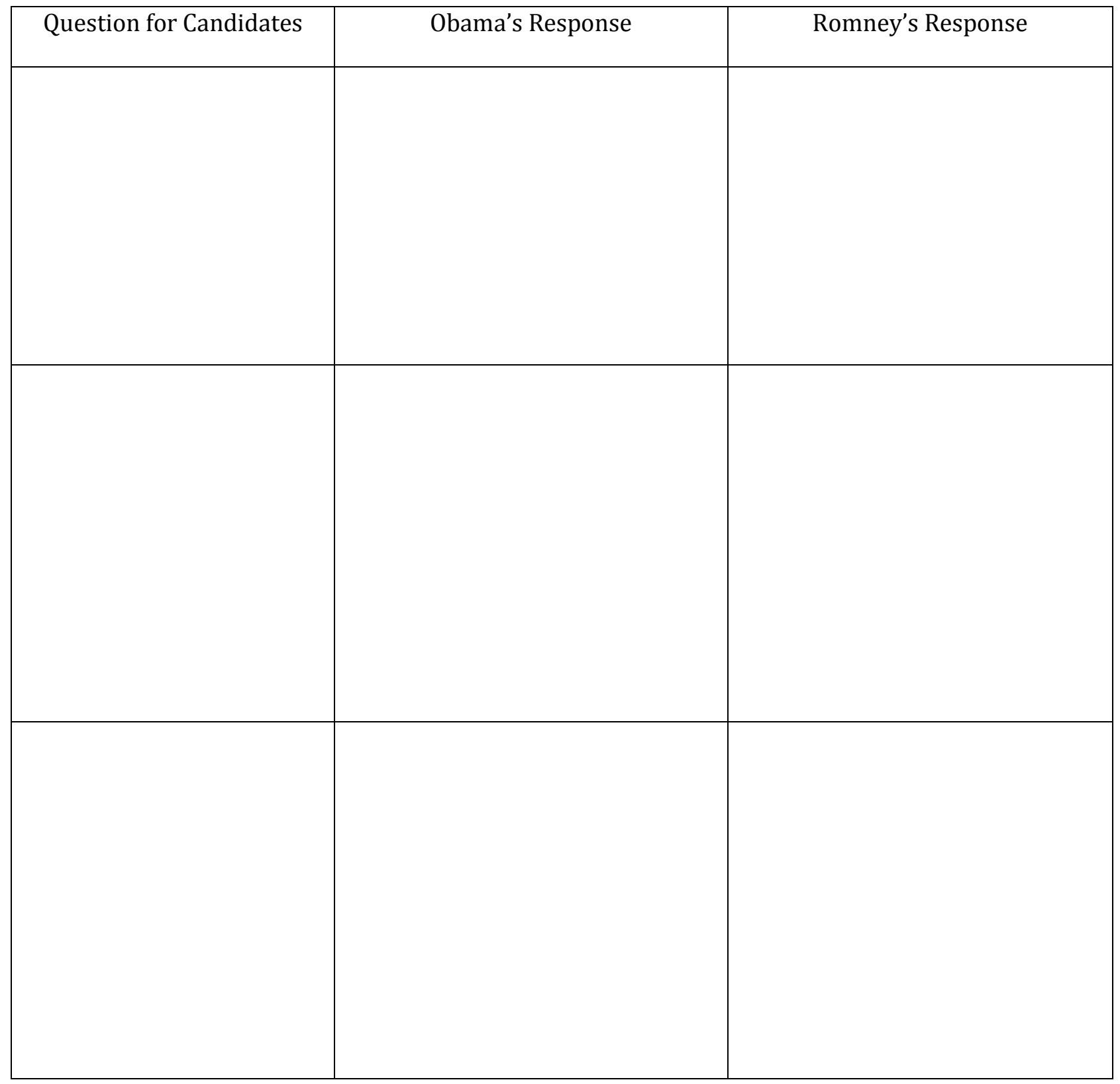

